\title{
Permainan Halang Rintang untuk Meningkatkan Motorik Kasar Pada Anak Usia Dini yang Mengalami Obesitas
}

\author{
Syafura Audina ${ }^{*}$, Panggung Sutapa ${ }^{1}$ \\ ${ }^{1}$ Universitas Negeri Yogyakarta, Yogyakarta, Indonesia \\ *email: syafura.a.2017@student.uny.ac.id
}

Abstract. The Benefit of Halang Rintang Game to Increase Obese Children Gross Motoric Development. Gross motor development becomes important because by mastering the ability to move, children will be able to interact with their environment. The purpose of this study was to determine the effectiveness of Halang Rintang game toward children gross motoric.The effectiveness of Halang Rintang game was evaluated by designing learning activities conducted by quasi-experimental method for 15 children. The results showed that there was a significant increase in obese children gross motoric development by $66.7 \%$.

Keywords: halang rintang game, gross motor skill, childhood obesity.

\begin{abstract}
Abstrak. Permainan Halang Rintang untuk Meningkatkan Motorik Kasar Pada Anak Usia Dini yang Mengalami Obesitas. Tujuan Perkembangan motorik kasar menjadi penting karena dengan menguasai kemampuan bergerak anak akan dapat berinteraksi dengan lingkungannya. Tujuan dari penelitian ini adalah untuk mengetahui efektivitas permainan halangan terhadap motorik kasar anak. Efektivitas permainan rintangan dievaluasi dengan merancang kegiatan pembelajaran yang dilakukan dengan metode kuasi-eksperimental untuk 15 anak. Hasil penelitian menunjukkan bahwa ada peningkatan yang signifikan dalam perkembangan motorik kasar anak usia dini sebesar $66,7 \%$.
\end{abstract}

Kata Kunci: permainan rintangan, motorik kasar, obesitas 


\section{PENDAHULUAN}

Dalam beberapa tahun terakhir, prevalensi obesitas pada anak telah meningkat secara signifikan, Kemudian masalah kelebihan berat badan pada anak-anak sering dikaitkan dengan perkembangan motorik yang buruk, terutama dalam keterampilan motorik kasar. Penguasaan keterampilan motorik kasar pada anak-anak sangat penting dalam membantu kegiatan anak-anak seperti olahraga, permainan, dan kegiatan rekreasi. Obesitas adalah kondisi akumulasi lemak yang abnormal atau berlebihan pada jaringan adiposa. Obesitas pada anak-anak adalah masalah kesehatan karena prevalensi obesitas anak di dunia meningkat. Di Indonesia, berdasarkan data Riskesda oleh Kementerian Kesehatan Republik Indonesia pada 2013, prevalensi kelebihan berat badan dan obesitas pada anak usia 5-12 tahun mencapai 18,8\%. Provinsi yang memiliki prevalensi di atas rata-rata nasional salah satunya adalah Kementerian Kesehatan RI Jawa Timur, 2013.

Obesitas pada anak dapat menjadi penyakit penyerta seperti asma, diabetes, dan penyakit kardiovaskular . Meskipun mekanisme terjadinya tidak sepenuhnya dipahami, telah dikonfirmasi bahwa obesitas terjadi karena asupan energi melebihi pengeluaran energi. Penyebab obesitas dipengaruhi oleh genetika dan lingkungan. Selain asupan energi, pengeluaran energi juga memengaruhi timbulnya obesitas seperti aktivitas fisik. Aktivitas anak-anak lain seperti bermain seharusnya tidak hanya menjadi aktivitas fisik biasa, tetapi alat belajar yang menyenangkan dan berolahraga secara tidak langsung. Bermain oleh seorang anak diharapkan untuk memainkan permainan yang berguna dari kekuatan otot dan fisik, keterampilan komunikasi, sosialisasi, sehingga dapat menyehatkan anak.

Perkembangan motorik adalah perkembangan kontrol gerakan tubuh melalui gerakan terkoordinasi antara sistem saraf, otot, otak dan sumsum tulang belakang. Kemampuan motorik dibagi menjadi dua yaitu motor kasar dan motorik halus tetapi disini penulis fokus pada motorik kasar anak. Motor kasar memiliki peran yang sangat penting dalam kesehatan. Perkembangan motorik halus dapat didefinisikan sebagai pengembangan gerakan yang tepat, yang menggunakan otot kecil untuk mengontrol gerakan kecil tangan, pergelangan tangan, jari, kaki, jari kaki, bibir, dan lidah.

Perkembangan motorik kasar didefinisikan sebagai perkembangan gerakan yang menggunakan otot besar seperti berjalan, menendang, dan melempar. Lima tahun pertama pertumbuhan dan perkembangan anak disebut masa keemasan karena pada saat itu situasi fisik dan semua kemampuan anak tumbuh cepat. Pesatnya perkembangan yang dialami oleh anak fisik menjadi penanda bahwa anak adalah individu yang aktif yang harus kita sebagai orang tua harus tahu bagaimana mengarahkan aktivitas motorik anak. Anak-anak memperoleh keterampilan motorik kasar baru yang paling sukses selama prasekolah dan sekolah dasar dan mampu menguasai keterampilan ini lebih mudah selama periode ini daripada titik lain dalam hidup mereka.

\begin{tabular}{rrr}
\multicolumn{2}{c}{ Perkembangan } & kemampuan \\
motorik anak-anak membutuhkan \\
aktivitas fisik untuk tumbuh dan
\end{tabular} berkembang dengan baik. Bentuk kegiatan bermain yang memacu penggunaan otot besar, permainan sederhana, mencoba, mengembangkan kerja sama, menggunakan sarana bermain dengan ukuran besar berbeda- 
beda. Permainan ini adalah alat bagi anak untuk menjelajahi dunianya, dari apa yang tidak diketahuinya hingga apa yang ia ketahui dan dari apa yang tidak dapat ia lakukan untuk itu. Permainan ini adalah alat pendidikan karena memberi rasa kepuasan, kegembiraan, dan kebahagiaan gim adalah alat pendidikan karena memberi rasa kepuasan, kegembiraan, dan kebahagiaan, melalui permainan, anak dapat menuai manfaat untuk pengembangan aspek fisik-motorik, dan emosional sosial.

Salah satu permainan yang dapat digunakan untuk meningkatkan motorik kotor anak adalah permainan rintangan. Permainan halang rintang adalah pengalaman efektif anak usia dini dengan atau tanpa alat permainan yang dapat menghasilkan pemahaman atau informasi, memberikan kesenangan, dan mengembangkan imajinasi anak-anak. rintangan adalah aktivitas fisik dalam bentuk gerak lari atau lari melalui rintangan. Rintangan datang dari lari lintas alam, dan rintangan adalah kombinasi dari lari jarak jauh, rintangan, rintangan, dan lompatan air. Dalam perkembangan seorang anak, keadaan fisik motor sangat diperhatikan dan menjadi diskusi, karena proses tumbuh kembang anak akan mempengaruhi kehidupan mereka di masa depan.

Beberapa penelitian telah meneliti perkembangan motorik kasar obsesif pra-sekolah anak-anak obesitas. Namun, penelitian sebelumnya hanya membahas perbedaan motorik kasar antara anak-anak obesitas dan anakanak normal, meskipun dalam penelitian ini akan memberikan solusi bagaimana meningkatkan motorik kasar terutama untuk anak-anak obesitas dengan aktivitas yang menyenangkan yaitu melalui permainan rintangan. Penelitian ini disusun sebagai berikut:
Bagian II menjelaskan materi dan metodologi yang diusulkan. Bagian III menyajikan hasil yang diperoleh dan diikuti dengan pembahasan. Akhirnya, Bagian IV kesimpulan dari penelitian ini.

\section{METODE}

Jenis penelitian yang dilakukan adalah kuantitatif dengan metode eksperimen semu. Subjek penelitian adalah 15 anak yang mengalami obesitas. Tujuan dari penelitian ini adalah untuk meningkatkan keterampilan motorik kasar anak usia dini yang mengalami obesitas. Lembar observasi dirancang untuk mengukur kemampuan kognitif anak usia dini sebelum dan sesudah perawatan. Pra-tes dan post-tes dilakukan untuk menentukan efek permainan halang rintang pada keterampilan motorik anak-anak. Dalam penelitian ini, lembar observasi disesuaikan dengan kebutuhan penelitian yang telah dibuat dengan menyesuaikan dengan Peraturan Pemerintah Menteri Pendidikan dan Kebudayaan Republik Indonesia Nomor 137 pada tahun 2014. Semua item pada lembar pertanyaan diukur dengan 3 Skala titik likert pada Tabel (1).

Tabel 1. Instrumen kemampuan motorik anak usia 5-6 tahun

\begin{tabular}{|c|c|c|c|c|}
\hline Aspek & Indikator & Baik & Cukup & Kurang \\
\hline $\begin{array}{c}\text { Motorik } \\
\text { Kasar }\end{array}$ & $\begin{array}{l}\text { Berjalan } \\
\text { cepat dengan } \\
20 \text { meter } \\
\text { Berjalan } \\
\text { cepat dengan } \\
20 \text { meter } \\
\text { Berjalan di } \\
\text { atas catwalk, } \\
\text { semua balok } \\
4 \text { meter } \\
\text { Lompat } \\
\text { menggunakan } \\
\text { dua kaki }\end{array}$ & & & \\
\hline
\end{tabular}




\begin{tabular}{|c|c|}
\hline $\begin{array}{l}\text { Metode } \\
\begin{array}{c}\text { Penelitian } \\
\text { metode }\end{array} \\
\begin{array}{c}\text { ini } \\
\text { kuasi- } \\
\text { eksperimental. }\end{array} \\
\text { perlakuan untuk anak-anak berusia 5-6 } \\
\text { tahun, pre-tes pertama kali dilakukan } \\
\text { untuk menentukan keterampilan } \\
\text { motorik kasar anak. Kemudian anak- } \\
\text { anak diberikan perlakuan dengan } \\
\text { menerapkan permainan halang rintang } \\
\text { dalam proses belajar setelah diberi } \\
\text { perlakuan anak kemudian dilakukan } \\
\text { post test lagi untuk mengetahui efek }\end{array}$ & $\begin{array}{l}\text { Pembelajaran } \begin{array}{c}\text { berbasis } \\
\text { mewujudkan pembelajaran }\end{array} \\
\text { dilakukan di lingkungan karena } \\
\text { membutuhkan halaman yang luas. } \\
\text { Pembelajaran ini dirancang } \\
\text { menggunakan permaianan yang } \\
\text { dilakukan di luar ruangan. permainan } \\
\text { yang digunakan dalam penelitian ini } \\
\text { adalah dalam bentuk beberapa posting } \\
\text { aktivitas. Dalam satu pos kegiatan ada } \\
\text { satu kendala yang harus dilalui oleh } \\
\text { anak }\end{array}$ \\
\hline
\end{tabular}
permainan halang rintang pada keterampilan motorik anak. Kriteria penilaian diperoleh melalui perhitungan di bawah ini:

$\begin{aligned} \text { Mean } & =\frac{N \max -N \min }{2}+N \min \\ \text { SD } & =\frac{\text { Mean }}{6} \\ & =\frac{12-4}{2}+4 \\ & =\frac{8}{6}=1,33 \\ & =8+8=16 \\ & \text { Baik }=>9.33 \\ \text { Kategori : } & \text { Sedang }=6.67-9.33 \\ & \text { Kurang }=<6.67\end{aligned}$

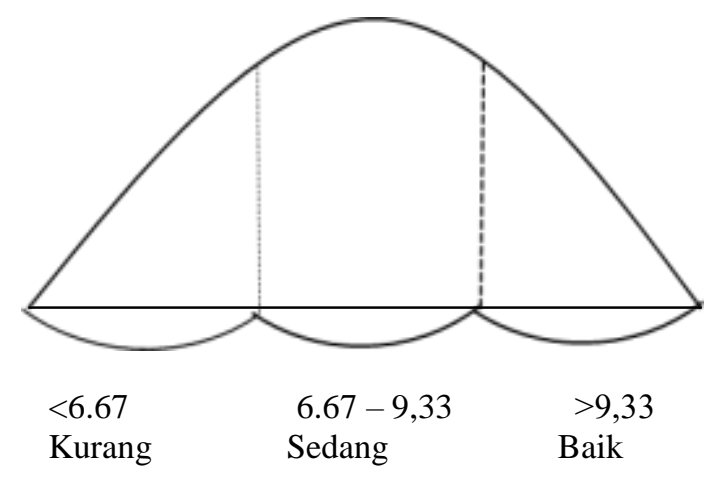

Desain percobaan Sebelum permainan rintangan dilakukan, pre-tes dilakukan untuk anak untuk mengetahui keterampilan motorik anak sebelumnya. Kemudian, setelah menerapkan permainan rintangan, posttest dilakukan lagi untuk mengetahui perbedaan dalam keterampilan motorik sebelum dan sesudah perlakuan dilakukan.

\section{HASIL DAN PEMBAHASAN}

Dalam penelitian ini, peneliti menguji asumsi sebelum menguji hipotesis. Uji asumsi adalah uji normalitas, uji homogenitas, uji linieritas. Asumsi atau hipotesis uji digunakan untuk memverifikasi hipotesis penelitian dan kapan Asym muncul. Uji Sig mencapai $p<0,05$, ini menunjukkan bahwa hipotesis diterima. Jadi disimpulkan bahwa pembelajaran alami dapat secara signifikan meningkatkan keterampilan motorik anak usia dini. Deskripsi hasil pengembangan motorik kasar Dari penelitian yang dilakukan, skor pre-test rata-rata untuk anak-anak berusia 5-6 tahun adalah 5,53 dan setelah pembelajaran berbasis alam diperoleh skor post-test adalah 9,86 sehingga ada perubahan yang signifikan antara keterampilan motorik kasar. pada anakanak sebelum dan sesudah penerapan permainan halang rintang.

Tabel 2. Deskripsi Hasil Pengembangan Motorik Kasar

\begin{tabular}{ccccccc}
\hline & $\mathrm{N}$ & Min & Max & Sum & Mean & Std. Dev \\
\hline Pre-test & 15 & 4.00 & 8.00 & 82.00 & 5.4667 & 1.12546 \\
Post-test & 15 & 7.00 & 12.00 & 150.00 & 10.0000 & 1.55839 \\
Valid N & 15 & & & & & \\
(listwise) & & & & & & \\
\hline
\end{tabular}


Jurnal Pendidikan Anak, April 2020, p :29-37

E-ISSN: 2580-9504

Dari diatas, untuk mengetahui untuk menguji hipotesis atau hubungan, peneliti terlebih dahulu menguji asumsi dalam bentuk uji normalitas, uji homogenitas dan uji linieritas sebagai syarat dalam penggunaan analisis uji-t. Kategori: Baik $=>$ 9,33 Cukup $=6,67$ 9,33 Kurang $=<6,67$

a) UJi Normalitas

Uji normalitas dilakukan untuk menentukan apakah distribusi data normal atau tidak. Hasil uji normalitas dapat dilihat pada Tabel (3) berikut:

Tabel 3. Uji Normalitas

\begin{tabular}{llrr}
\hline & & $\begin{array}{r}\text { pre-test } \\
\text { post- } \\
\text { test }\end{array}$ \\
\hline $\mathrm{N}$ & Mean & 15 & 15 \\
Parameters & 5.4667 & 10.0000 \\
& & & \\
& Std. & 1.12546 & 1.55839 \\
Most Extreme & Deviation & & \\
Differences & Absolute & .194 & .167 \\
& Positive & .194 & .100 \\
& Negative & -.149 & -.167 \\
Test Statistic & & .194 & .167 \\
$\begin{array}{l}\text { Asymp. Sig. (2- } \\
\text { tailed) }\end{array}$ & & $.133^{\mathrm{c}}$ &, $200^{\mathrm{c}, \mathrm{d}}$ \\
\hline
\end{tabular}

Diketahui bahwa nilai sig sebelum perlakuan adalah 0,133 dan nilai sig setelah perlakuan adalah 0,200 yang berarti bahwa nilai Sig> 0,05 maka data terdistribusi secara normal.

b) Uji Homogenitas

Uji homogenitas bertujuan untuk memberikan keyakinan bahwa satu set data yang dimanipulasi dalam serangkaian analisis berasal dari populasi yang tidak jauh berbeda dalam hal keanekaragaman.

Tabel 4. Uji Homogenitas

\begin{tabular}{lrr}
\hline & pre-test & \multicolumn{1}{c}{ post-test } \\
\hline Chi-Square & $5,333^{\mathrm{a}}$ & $2,200^{\mathrm{b}}$ \\
df & 4 & 5
\end{tabular}

\begin{tabular}{lll} 
Asymp. Sig. &, 255 & ,821 \\
\hline
\end{tabular}

\section{Vol. 6, No. 1}

DOI:

Berdasarkan Tabel IV di atas, nilai Asymp sig diperoleh sebelum perlakuan 0,255 dan setelah pengobatan 0,821 nilainya lebih besar dari 0,05 . Jadi dapat disimpulkan bahwa kedua kelompok itu homogen atau memiliki varian yang sama.

c) Uji Linearitas

Pengujian linearitas bertujuan untuk mengetahui apakah data memiliki garis linier atau tidak (apakah hubungan antar variabel yang akan dianalisis mengikuti garis lurus atau tidak). Hasil uji linearitas dapat dilihat pada Tabel (5) berikut:

Tabel 5. Uji Linearitas

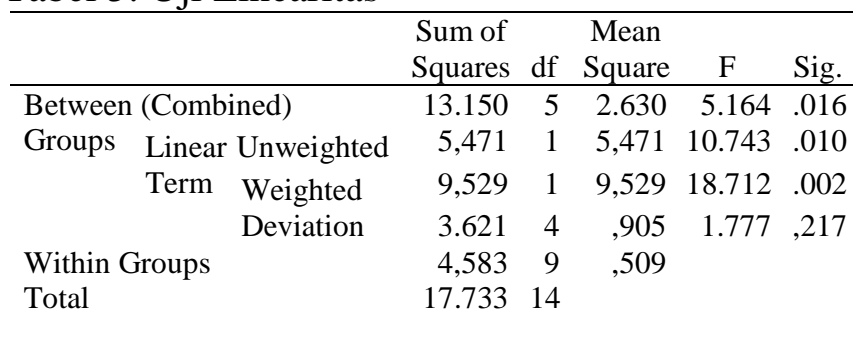

Dalam pengujian linearitas, ketentuan berlaku jika pada deviasi sig> 0,05, hubungan antar variabel bersifat linier. Sebaliknya, jika deviasi sig adalah <0,05) maka hubungan antar variabel tidak linier. Tabel data menunjukkan bahwa sig adalah 0,217, nilainya lebih besar dari $0,05 \quad(0,217>0,05)$ sehingga disimpulkan bahwa hubungan antar variabel adalah linier.

d) Uji Hipotesis

Uji Hipotesis setelah menguji asumsi, langkah selanjutnya adalah menguji hipotesis. Pengujian hipotesis dilakukan untuk melihat perkembangan motorik kasar anak-anak berusia 5-6 tahun setelah diberi 
Jurnal Pendidikan Anak, April 2020, p :29-37

E-ISSN: 2580-9504

perlakuan dengan menerapkan permainan halang rintang, sehingga perlu untuk melihat hubungan antara data pre-test dan post-test seperti Tabel (6)

Tabel 6. Uji Hipotesis

\begin{tabular}{|c|c|c|c|c|c|c|c|c|}
\hline & & Pairec & Differe & nces & & & & \\
\hline & & & & & & & & \\
\hline & & Std. & $\begin{array}{l}\text { Std. } \\
\text { Error }\end{array}$ & $\begin{array}{l}\text { Conf } \\
\text { Interva }\end{array}$ & $\begin{array}{l}\text { dence } \\
l \text { of the }\end{array}$ & & & $\begin{array}{l}\text { Sig. } \\
\text { (2- }\end{array}$ \\
\hline & Mean & $\begin{array}{l}\text { Deviati } \\
\text { on }\end{array}$ & $\begin{array}{c}\text { Mea } \\
n\end{array}$ & $\begin{array}{l}\text { Diffe } \\
\text { Lower }\end{array}$ & $\begin{array}{l}\text { rence } \\
\text { Upper }\end{array}$ & $\mathrm{t}$ & $\begin{array}{l}d \\
f\end{array}$ & $\begin{array}{l}\text { taile } \\
\text { d) }\end{array}$ \\
\hline Pai pre & & & & & & & & \\
\hline r 1 - test & - & & & - & - & - & & \\
\hline- & 4,533 & 1.06010 & ,2737 & 5.120 & 3,946 & 16,56 & 1 & .000 \\
\hline pos & 33 & & 2 & 40 & 27 & 2 & 4 & \\
\hline $\begin{array}{l}\mathrm{t}- \\
\text { test }\end{array}$ & & & & & & & & \\
\hline
\end{tabular}

Dengan ketentuan jika nilai $\mathrm{P}<0,05$, ada perbedaan antara hasil pre-test dan posttest. Dan jika P>0,05, tidak ada perbedaan antara hasil pre-test dan post-test. Berdasarkan tabel di atas menunjukkan perbedaan rata-rata 4,53 dan nilai $\mathrm{P}$ (2 tailed) sebesar 0,000 berarti bahwa nilai sig $<0,05$ sehingga dapat disimpulkan bahwa terdapat perbedaan nilai setelah perlakuan dan mengalami peningkatan yang signifikan dan menunjukkan bahwa ada perbedaan antara hasil pre-test dan post-test.

Perbandingan

rekapitulasi hasil pre-test-posttest dapat dilihat pada Tabel (7) dan Gambar 1 di bawah ini:

Tabel 7. Pre-Test-Post-Test Tabel

\begin{tabular}{llllllll}
\hline No & Category & Categor & \multicolumn{2}{l}{ Score } & \multicolumn{2}{c}{ Pre-test } & \multicolumn{2}{c}{ Post-test } \\
& & $\mathrm{y}$ & Range & $\mathrm{F}$ & $\%$ & $\mathrm{~F}$ & $\%$ \\
\hline 1. & Good & $66.7 \%-$ & $>9,33$ & 0 & 0 & 10 & 66.7 \\
& & $100 \%$ & & & & & $\%$ \\
2. & \multirow{2}{*}{ Sufficient } & $33,4 \%-$ & $6.67-$ & 2 & $13,3 \%$ & 5 & 33,3 \\
& & $66.6 \%$ & 9,33 & & & & $\%$ \\
3. & Less & $0,5 \%-$ & $<6.67$ & 13 & $86.7 \%$ & 0 & 0 \\
& & $33,3 \%$ & & & & & \\
\hline
\end{tabular}

\section{Vol. 6, No. 1}

DOI:

Berdasarkan Tabel VII, diketahui bahwa semua anak mengalami peningkatan. dalam perkembangan kognitif, pertama: ini dapat dilihat pada anak-anak dalam kategori baik $0 \%$ hingga $66,7 \%$, hanya $13,3 \%$ menjadi $33,3 \%$ dan kurang dari $86,7 \%$ hingga 0\%. Deskripsi hasil perbandingan sebelum dan sesudah perlakuan dapat dilihat pada grafik berikut:

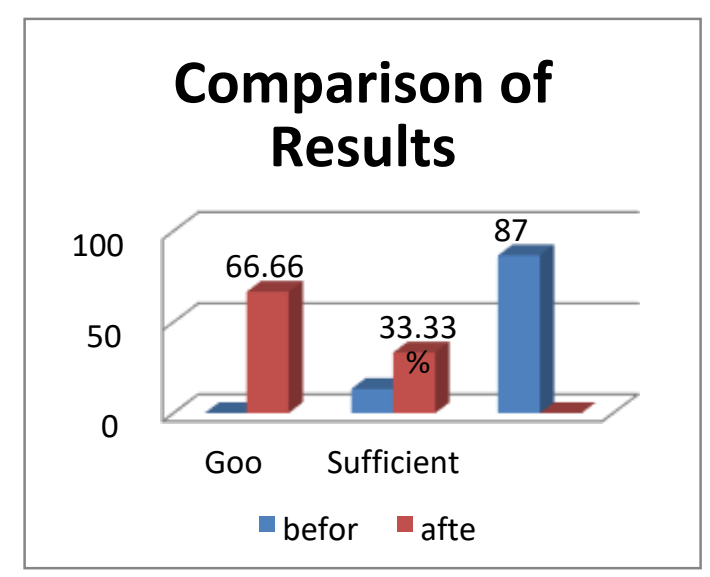

Gambar 1. Perbandingan perkembangan kognitif anak sebelum dan sesudah pembelajaran berbasis alam

Berdasarkan Gambar 1 di atas. perbandingan sebelum dan sesudah diketahui bahwa semua anak mengalami peningkatan perkembangan motorik kasar. Ini berarti bahwa permainan Halang rintang mempengaruhi secara signifikan pada pengembangan motorik kasar.

Masa kanak-kanak adalah periode kritis yang harus dipertimbangkan untuk mendukung pengembangan keterampilan motorik kasar. Anak-anak prasekolah tentu suka bermain dan menjelajahi lingkungan sekitarnya; dengan demikian, mereka dapat mengembangkan keterampilan motorik dengan sangat mudah.

$$
\text { Pada saat kritis ini, }
$$
perkembangan motorik kasar sangat 
tepat bagi anak-anak untuk bergerak, menstabilkan tubuh, menjaga keseimbangan dan menjelajahi lingkungan sekitarnya. Penelitian ini menerapkan permainan halang rintang untuk meningkatkan keterampilan motorik kasar anak-anak karena pembelajaran ini diyakini dapat mengoptimalkan semua aspek perkembangan pada anak usia dini. Hasil pre-test menunjukkan bahwa $86,7 \%$ anak-anak berada dalam kategori buruk dan tidak ada anak-anak dalam kategori baik.

Anak-anak berusia 5-6 tahun harus sudah memiliki pengetahuan motorik kasar yang baik. Berbagai faktor, baik internal maupun eksternal, menyebabkan motorik kasar anak-anak rendah. Setelah observasi, yang merupakan penyebab rendah motorik kasar, anak-anak adalah proses implementasi dalam pembelajaran yang cenderung ceramah dan jarang melakukan aktivitas fisik di luar ruangan. Kemudian, peneliti menerapkan permainan halang rintang sebagai model pembelajaran yang menyenangkan, anak sebagai pembelajar aktif dan dilakukan dengan bermain.

Penelitian ini melibatkan 2 guru TK, pengobatan dilakukan 4 kali untuk membuktikan bahwa permainan rintangan dapat meningkatkan motorik kasar anak-anak. Hasil penelitian menunjukkan bahwa anak motorik kasar meningkat secara signifikan menjadi $66,7 \%$ yang termasuk dalam kategori baik. Dalam kurun waktu 1 bulan, penelitian ini dikatakan berhasil karena meningkatkan perkembangan motorik kasar anak-anak.

Selain sebagai pembelajaran yang menyenangkan dan anak-anak sebagai pembelajar aktif dan memiliki keterampilan motorik kasar yang baik. Dalam beberapa tahun terakhir, penilaian kinerja keterampilan motorik kasar anak-anak telah meningkat secara signifikan, terutama hubungan antara obesitas anak dan perkembangan motorik kasar. Bukti anak-anak obesitas memiliki keterampilan motorik kasar yang lebih buruk daripada anak-anak dengan berat badan normal.

Sebuah studi baru-baru ini menilai keterampilan motorik di antara anak-anak yang obesitas, dan melaporkan bahwa keterampilan motorik terkait buruk dengan obesitas pada masa kanak-kanak hanya untuk keterampilan yang paling langsung terkait dengan penambahan berat badan, seperti melompat dan melompat. Berbeda dengan temuan kami, kinerja keterampilan motorik kasar anak-anak prasekolah yang obesitas dapat meningkat dengan menggunakan kegiatan permainan halang rintang yang membuat anak-anak antusias untuk melakukan gerakan motorik kasar karena dikemas dalam permainan yang menarik.

\section{SIMPULAN DAN SARAN}

Keterampilan motorik kasar berkaitan erat dengan olahraga dan aktivitas fisik. Bahkan, fokus pada pengembangan motorik kasar memiliki implikasi untuk pengembangan orangorang olahraga yang sangat terampil. Obesitas pada masa kanak-kanak adalah salah satu faktor yang berpengaruh negatif terhadap perkembangan dan kinerja keterampilan motorik kasar, sehingga harus dianggap sebagai masalah serius. Dalam hal ini mengidentifikasi masalah perkembangan motorik kasar anak-anak sangat penting terutama bagi anak-anak yang mengalami obesitas, karena anakanak obesitas identik dengan lemahnya perkembangan motorik kasar. Semakin sering diberikan rangsangan dengan melakukan aktivitas fisik tentu akan 
membantu mengatasi masalah perkembangan motorik anak yang mengalami obesitas.

Penelitian ini menyelidiki pengaruh pembelajaran berbasis alam untuk meningkatkan keterampilan motorik kasar anak usia dini. Hasil penelitian eksperimental menunjukkan bahwa permainan hambatan secara signifikan mempengaruhi keterampilan motorik kasar pada anak usia dini. Tujuan pembelajaran tidak hanya untuk mengembangkan keterampilan motorik kasar tetapi juga toleransi dan sikap kooperatif.

\section{REFERENSI}

Agnes, W.Y.P., Daniel, T.P.F. (2009). Fundamental Motor Skill Proficiency Of Hong Kong Children Aged 6-9 Years. "Research in Sports Medicin" 17 125-144.

Allwod, J. (2003). Governing Early Childhood Education through Play. "Contemporary Issues in Early Childhood. Charles Sturt University, Australia".

Biro FM, Wien M. (2010). Childhood Obesity And Adult Morbidities. "Am J CLIN Mutr" 91: 1499-1505

Carr, Gerry A. (2003). Atletik Untuk Sekolah. Jakarta: PT. Raja Graffindo Persaja.

Castetbon, K., Andreyeva, T. (2012). Obesity and Motor Skills Among 4 To 6- Year-Old Children in the United States: NationallyRepresentative Surveys. "BMC pediatrics" 12(1), 28.

Cools, W., et al. (2008). Movement Skill Assessment Of Typically Developing Preschool Children: A Review Of Seven Movement Skill Assessment Tools. "Journal of Sports Science and Medicine" 8, 154-168,

Gallahue, D.L., Ozmun, J. C. (1998). Motor Development Infants, Children, Adolescents, Adults (fourth ed.): McGraw-Hill.

Graf, C., et al. (2004). Correlation Between Bmi, Leisure Habits And Motor Abilities In Childhood. International Journal of Obesity. 28, 22-26.

Hasnida. (2014) Analisis Kebutuhan AUD. Jakarta: PT. Luxima Metro Media.

Lob-Corzilius, T. (2007). Overweight and obesity in childhood: A special challenge for public health. "International journal of hygiene and environmental health" 210 (5), 585-589.

Maidelwita Y. (2013). Pengaruh Faktor Genetik., Pola Konsumsi dan Aktivitas Fisik dengan Kejadian Obesitas Pada Anak kelas 4-5 SD SBI prescobaan Ujung Gurun Padang. Mercubaktijaya Journal.

Maryanne Thobald. (2017). Children's Perspectives of Play and Learning for Educational Practice. Education Sciences. www.mdpi.com/journal/education

Mochamad Djumidar. (2004). GerakGerak Dasar Atletik Dalam Bermain. Jakarta: PT. Raja Garafindo Persada

Okely, A.D., Booth, M.L., Chey, T. (2004). Relationships Between Body Composition And Fundamental Movement Skills Among Children And Adolescents. Research Quarterly for Exercise and Sport. 75, 238248.

Olrich, T.W. (2002). Assessing fundamental motor skills in the elementary school setting. Issues

Onis M, Bloosner M, Borghi E. (2008). Global prevalence and trends of 
overweight and obesity among preschool children. Am J Clin Nutr. 1257-1264.

Payne, V.G., Isaacs, L.D. (2005). Human Motor Development (6th ed.): William Glass.

Skogheim TS, Vollrath ME. (2015). Associations of Child Temperament with Child Overweight and Breakfast Habits. "A Population Study in Five YearOlds. Nutrients" 7, 10116-10128.
Soetjiningsih, D. (1995). Tumbuh kembang anak. Jakarta: Penerbit Buku Kedokteran EGC, 1, 995.

Sujiono \& Yuliani. (2010).Bermain Kreatif Berbasis Kecerdasan Jamak. Jakarta: Indeks.

Wang, Y., Lobstein, T. (2006). Worldwide Trends In Childhood Overweight And Obesity. "International Journal of Pediatric Obesity” 1(1), 11-25. 